\title{
Review \\ The Development and Issues of Energy-ICT: A Review of Literature with Economic and Managerial Viewpoints
}

\author{
Jin-Li Hu ${ }^{1, *\left(\mathbb{D}, \text { Yi-Chou Chen }{ }^{1,2} \text { (D) and Ya-Po Yang }\right.}{ }^{3}$ \\ 1 Institute of Business and Management, National Yang Ming Chiao Tung University, \\ Taipei City 10044, Taiwan; cycu.chou@gmail.com \\ 2 Department of General Education, National Army Academy, Taoyuan City 320316, Taiwan \\ 3 Institute of Business and Management, National University of Kaohsiung, \\ Kaohsiung City 81148, Taiwan; yapo@nuk.edu.tw \\ * Correspondence: jinlihu@nycu.edu.tw; Tel.: +886-2-23812386 (ext. 57641)
}

check for updates

Citation: Hu, J.-L.; Chen, Y.-C.; Yang, Y.-P. The Development and Issues of Energy-ICT: A Review of Literature with Economic and Managerial Viewpoints. Energies 2022, 15, 594. https://doi.org/10.3390/en15020594

Academic Editors: Eul-Bum Lee and Devinder Mahajan

Received: 31 October 2021

Accepted: 11 January 2022

Published: 14 January 2022

Publisher's Note: MDPI stays neutral with regard to jurisdictional claims in published maps and institutional affiliations.

Copyright: (c) 2022 by the authors. Licensee MDPI, Basel, Switzerland. This article is an open access article distributed under the terms and conditions of the Creative Commons Attribution (CC BY) license (https:// creativecommons.org/licenses/by/ $4.0 /)$.

\begin{abstract}
This paper reviews the economic and managerial literature on the relationship between energy-ICT and the development of the green energy economy. It is summarized that there are four lines of existing literature on energy-ICT: cost and benefit analysis, fair competition issues, cybersecurity issues, and promotion policy issues. Even though ICT is energy-consuming, most of the existing empirical studies support the idea that energy-ICT has net positive effects on energy savings, energy efficiency improvement, emission reduction, and economic growth at both enterprise and economy-wide levels. Energy-ICT equips the platform operator with higher bargaining power, such that a governance mechanism to assure the fair access right of each entitled participant is required. A smarter energy-ICT network also becomes riskier, and hence the cybersecurity protection is more important than before. Future research and development opportunities remain on these issues of the fair competition, cybersecurity, and promotion policy of energy-ICT.
\end{abstract}

Keywords: energy-ICT; cost and benefit; fair competition; cybersecurity; promotion policy

\section{Introduction}

A green energy economy is characterized by the use of renewable and low-carbon energy resources to maintain economic development on a sustainable energy basis [1,2]. However, due to weather and geographical conditions, renewable energy sources are often unstable. Information and communications technologies (ICTs) include all the related infrastructure that allows people to record and send information, connecting the world. The various ICT mediums are unanimously seen in all fields to be quickening agents, increasing productivity and efficiency through the utilization of high-speed information transmission. Therefore, ICTs are the must to integrate a smart energy system in such a way that the generation, storage, transmission, distribution, and usage of green energy can be integrated and managed in an environmentally friendly and economically efficient way [3,4]. In other words, the energy system can get 'smarter' by being integrated with ICTs. However, the energy system also becomes more complex by being a network interlinked by ICT [5].

Along with the energy-ICT framework, there has been the concept of the smart grid as an interconnected network of microgrids with a distributed control; it is a convergence of ICT and power systems. The smart grid facilitates the cogeneration and distribution of energy [6,7]. A smart grid is an interface between energy, ICT, urban systems, etc. [8]. That is, it is a network linking the energy, ICT, and urban systems together. A smart grid contains the power and the ICT systems, as well as other components. The energy-ICT literature reviewed in this paper then focuses on the integration of energy and ICT systems, which constitute the two integral pillars of the smart grid.

The general definition of green energy refers to energy sources from renewable and sustainable resources, such as water, sunlight, wind, geothermal energy, ocean currents, 
etc., [2-4]. There have been disputes about whether or not green energy sources can be reliably utilized as a part of the baseload power of the electricity supply for an economy. Usually, the main sources of the baseload power are coal-fired power stations or nuclear plants because they are relatively stable and can quickly increase or decrease the power supply through engineering control [9]. As Nijhuis et al. [4] show, renewable energy and ICT are two drivers of the transition of energy distribution networks. With the aid of the smart grid, the electricity supply from green energies sources can be integrated with other energy sources in a smart grid [4-9], not only to increase the energy efficiency but also to reduce the total emissions produced by effectively increasing the share of green energy for an enterprise or economy [9-14].

ICT can also be used as an effective tool to help manage energy efficiency in the household sector. An ICT device built in a household could instantly interact with the grid, turning a household into a more decentralized, renewable-energy-based, interconnected, and adjustable system. The system would help optimize the energy management for households, which would effectively improve energy efficiency [13]. That is, the energy efficiency improvement can start at the household level on a daily life basis.

As pointed out by the International Energy Agency [15], the energy sector has been adopting digital technologies since the 1970s. Power plants, electricity grids, and oil and gas companies all incorporate digital technologies into their operation and management strategies. Therefore, the relationship between energy production and ICTs is not a brand new concept in the energy sector in the world. However, it has become an increasingly developed business model, growing from merely applying ICT tools to including real-time energy production and management. The technology now also allows the integration of energy-related information and non-energy information to help achieve sustainable development goals (SDGs) at the microeconomic and macroeconomic levels.

ICT has shown its effectiveness in integrating different sectors and improving energy efficiency. Take the smart building as an example. ICT has been integrated at the core of smart buildings to monitor and adjust the energy used for insulation, heating, ventilation, cooling, appliances, etc. With the aid of ICT, small buildings can reduce energy consumption by up to $50 \%$. ICTs have helped with energy savings and energy efficiency in the transportation sector as well, improving goods distribution systems, such as those using railroads and trucks [16].

Thabit et al. [17] conclude that the six drivers for developing green ICT in developing economies are: costs, government legislation, political and social pressure, enlightened self-interest, environmental responsibilities for businesses, and new opportunities of the market. These six drivers also apply to the incorporation of ICT into a system such as energy. That is, ICT is an effective strategy for achieving both environmental and business purposes.

As mentioned above, energy-ICT brings with it new business models. Among them, there is a new business model called 'energy as a service' (EaaS). The International Renewable Energy Agency [18] summarizes that the energy service includes energy advice, energy assets, and energy management. All these components in EaaS are inter-connected by a smart grid. Energy savings, energy efficiency improvement, and energy flexibility can be achieved via EaaS. Energy consumers can benefit from electricity bill reduction and feel the improvement of the status quo in the short term.

This paper reviews the literature on energy-ICT from the economic and management viewpoints. We used the search engine Google Scholar to find related academic and technical documents. Along with 'energy' and ' $\mathrm{ICT}^{\prime}$ ', the search keywords also included 'green energy economy', 'cost and benefit', 'fair competition', 'fair trade', 'smart grid', 'platform', 'cybersecurity', and 'promotion policy'. Pure engineering and natural science papers were not included for this literature review. The academic papers with economic and managerial implications were retained for further detailed reading and then summarization. Technical reports from major international organizations were also downloaded from the Google search engine, using the keywords above. 
The conceptual framework of this paper is as depicted in Figure 1 and contains the following topics: the cost and benefit analysis of energy-ICT, the fair competition issues of energy-ICT, the cybersecurity issues of energy-ICT, and the promotion policies to promote the integration of energy production sectors and ICTs, or what we will henceforth refer to as "energy-ICT". Finally, we make suggestions for future research on energy-ICT from the economic and managerial viewpoints.

\section{Cost and Benefit Analysis of Energy-ICT}

Section 2

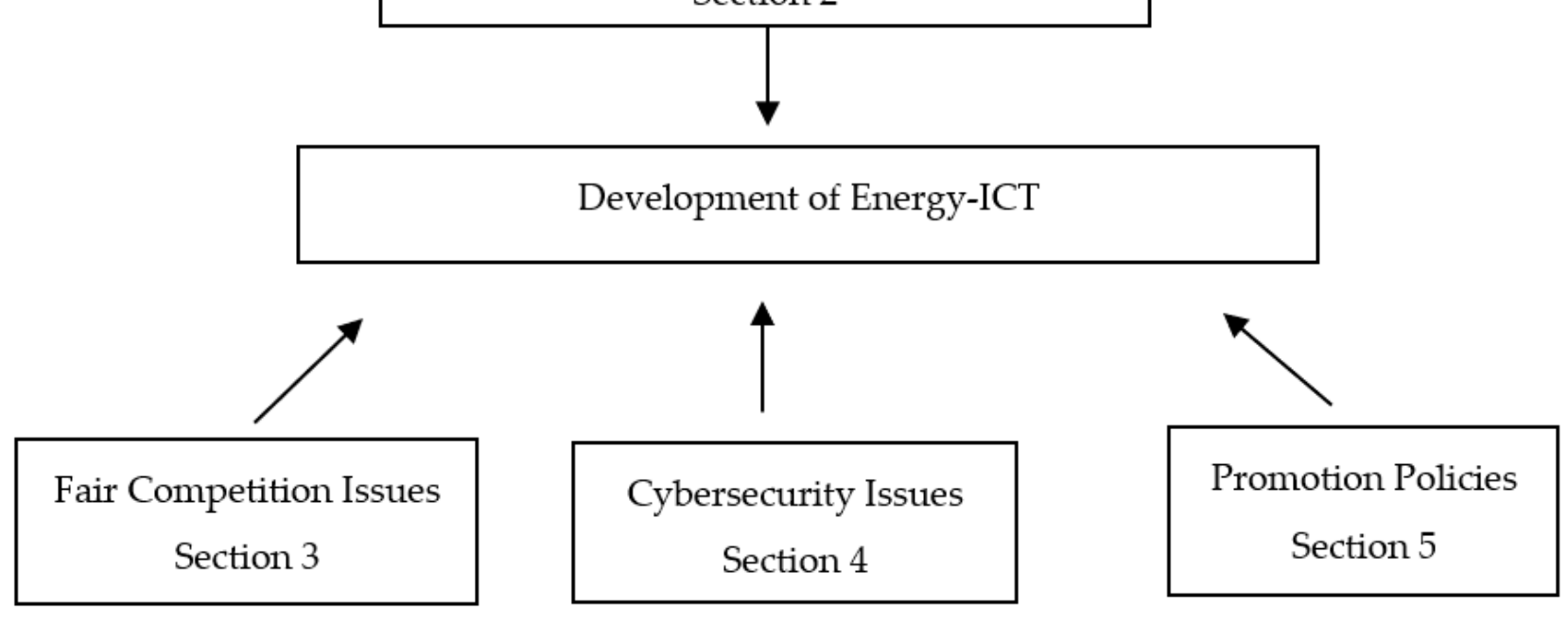

Figure 1. Energy-ICT Literature Review with Economic and Management Viewpoints.

\section{The Cost and Benefit of Energy-ICT on the Green Economic Development}

The literature on the cost and benefit analysis of energy-ICT can be categorized into four lines. The first is the effect on energy savings and consumption increase brought about by introducing ICT. The second is the impact of energy-ICT on energy efficiency. The third is the effect of energy-ICT on economic growth. The fourth is how energy-ICT helps in coping with the impacts brought by the COVID-19 pandemic.

\subsection{Energy Savings and Consumption Increase Effects of Energy-ICT}

The global energy production and consumption nowadays is widely managed by ICT. ICT is energy-intensive, but it also helps promote energy savings [19]. There are tradeoffs caused by integrating the ICT and energy systems. Many articles warn that ICT is energyintensive and hence may increase the energy consumption (see [19-24]). This is similar to the so-called 'rebound effect' in which the improved performance of electronic devices causes more energy consumption (and hence more emissions) in total [20]. Therefore, the energy-saving concerns should be taken into account in the ICT system design when the ICT technologies are embedded into the energy system. Consequently, in theory, it is very likely that the energy-saving effect of ICT dominates its energy-consuming effect, though this remains an empirical question.

Sugiyama [21] says that ICT itself consumes electricity, which emits $\mathrm{CO}_{2}$. On the other hand, ICT reduces $\mathrm{CO}_{2}$ emissions by improving the operational efficiency. The postulate is that the net effect of ICT is to reduce $\mathrm{CO}_{2}$ emission. If so, then society should be shifted to being an ICT-oriented one. The green ICT can help move toward a low-carbon society.

Santarius et al. [22] make a study on the trend of digitalization and ICT growth and its impact on the environment in a global economy. They observe that while this shift creates energy and resource efficiency, the production of the required materials that facilitate the change may have negative effects, but the study requires more empirical data for an 
accurate assessment. However, they conclude that political and societal shaping of the process of digitalization is needed to make ICTs work for global sustainability.

Klein and Richard [23] point out that network energy bills account for 10-15\% of the operational expenses of telecommunication service providers in developed economies and even up to $50 \%$ in developing economies. Consequently, the ICT industry has to efficiently manage its energy consumption to reduce the energy expenses. Using conceptual frameworks, Røpke and Christensen [24] indicate that ICT is energy-intensive in everyday life. They warn that the ICT it can be inadequate and can hence increase the energy consumption, and they suggest that economic and political conditions should be aligned with ICT integration to effectively reduce energy consumption.

Even though there are warnings that the introduction of ICT itself may increase energy consumption as well as carbon emissions, many empirical studies support the idea that the net effect of energy-ICT is to save energy and reduce emissions (see [12] and [25-40]). Bastida et al. [12] find that ICT has changed consumer behavior, hence reducing household final electricity consumption by 0 to $5 \%$ and then decreasing the GHG emissions generated by the electricity sector. Using global data globally from 2010-2015 and forecasts to 2020, Malmodin and Lundén [25] found that the ICT sector had generally turned the growing trend of the carbon footprint into a shrinking one. This implies that through continuous improvements, the global ICT sector can both save energy and reduce carbon emissions.

Tunali [26] estimates the impact of ICT development on the electricity consumption in European Union (EU) economies from 1990-2012. It was found that ICT development in the EU significantly increased its electricity consumption. Even though there might be an energy-consumption reduction effect by ICT, its energy-consumption enlargement effect is empirically found to dominate its energy-consumption reduction effect. Therefore, further measures should be taken in order to cope with the energy-consumption enlargement effect by ICT development.

By analyzing the Seventh Framework Programme documents published by the European Commission, Cakici and Bylund [27] point out that ICT-based surveillance still provides limited effects on changing the behavior of users. They, therefore, recommend that more factors should be taken into account in order to reshape the behavior of users in order to save energy and reduce carbon emissions.

Even though some of the earlier literature warns that ICT may increase energy consumption, the later literature indicates that ICT may help save energy. Forecasting by way of a theoretical model following six scenarios until 2050, Moyer and Hughes [28] find that without alignment with the environmental policy, ICT development has limited effects on reducing energy demand and carbon emissions. However, with the alignment of environmental policies such as carbon pricing, ICT development can have a downward impact on both energy demand and carbon emissions. Hence, they suggest that ICT development should be coupled with environmental policy in order to achieve sustainable results in 2050.

Niyibizi and Komakech [29] think that ICT is an enabling tool for developing countries to save energy and mitigate climate change. There are many ICT applications with respect to transportation, smart buildings, energy production and use, smart micro-grids, exportmanufacturing emission control, land use, forestry management, etc. For developing countries, ICT can save energy and reduce the carbon footprint.

Ngwenyama and Morawczynski [30] study ICT development in five Latin American countries which emphasize heavy investment and deregulation of related infrastructure in order to speed economic growth. Empirical results show that these countries fail to meet projected outcomes. They suggest that existing conditions, such as economic factors, human capital, geography, and civil infrastructure factors, must be also taken into account.

Via an international comparison, Ponce-Jara et al. [31] show that in both developed and developing countries, smart grids have brought with them many positive effects, including reductions in energy loss and power theft in countries such as Brazil and India. The developed countries have relatively more complete plans to integrate the generation, 
transmission, distribution, and storage stages by smart grids, whereas the developing countries start with relatively incomplete pilot projects in parts of these four stages.

Studying the regional data of Turkey, Colak et al. [32] conclude that smart grids can help develop renewable energy and improve energy transmission efficiency. They also confirm that the smart grids can effectively reduce transmission loss and electricity theft. The producer-consumer-university collaboration gets better by smart grids. This energyICT nexus does help Turkey as a developing country to attract more inward investment and boost its economy.

Most current empirical studies have supported the idea that energy-ICT does have many positive impacts on green economic development. Mattern et al. [33] point out that if the smart ICT can change the household behavior pattern, then, even though ICT is energy-intensive, the energy-saving effect can still dominate the energy-demanding effect of combining ICT and energy systems. They suggest that eMeters should be introduced to give real-time feedback to households so that the net effect of energy-ICT is energy-saving.

\subsection{Energy-Efficiency Improvement by Energy-ICT}

By using a theoretical model for simulation, Lange et al. [34] find that ICT can enhance production technology, improve energy efficiency, and foster economic growth by increasing input productivity. Therefore, the development of ICT can help reduce energy consumption. However, the ICT services themselves are energy-intensive in that they consume a lot of electricity to support their own activities. There are adverse effects that boost up energy consumption by expanding the ICT services.

Many existing papers find empirical evidence from various economies in the world to support the idea that energy-ICT has significant benefits on the promotion of energy efficiency, emissions reduction, and economic growth. Using numerical simulations, Molderink et al. [35] conclude that a smart grid integrating micro-generation, energy storage, and efficient appliances can effectively improve energy efficiency. This is because a smart grid optimizes multiple objectives at the same time, resulting in an optimization of the whole system. They think that by introducing smart grids, the achievement of desirable objectives is promising.

Reviewing the technology features of smart grids, Anjana and Shaji [36] point out that ICT as the core technology of smart grids collects data and provides optimized feedback, constituting a two-way communication path with consumers. Consequently, the energy-ICT nexus effectively reduces the energy cost and improves energy efficiency. They conclude that the smart grid is definitely the solution for the current power system improvement.

Yan et al. [37] analyze a panel dataset of 50 economies from 1995-2013. They conclude that ICT development has positive effects on energy productivity. ICT helps in saving energy and improving the energy productivity of these economies.

Schulte et al. [38] analyze a 13-year cross-country, cross-industry panel dataset which includes 10 OECD economies and 27 industries. Their results indicate that ICT significantly reduces the total energy demand. Moreover, the relative electric energy demand can also be significantly reduced by the development of ICT. Their results support the idea that ICT can bring net positive effects on energy savings.

Researching a panel dataset of 12 Asian countries from 1993-2013, Lu [39] finds that increases in carbon emissions mainly come from increases in energy consumption and GDP, whereas the development of ICT reduces carbon emissions. Therefore, ICT development can be a driving force for carbon emission reduction.

Chimbo [40] estimates the relationship between ICT, energy consumption, and economic growth by using a panel dataset of 20 African economies from 2001-2015. From an interaction term in the regression, it was found that ICT helps enhance energy efficiency and hence promotes economic growth. From another interaction term in the regression, it was also shown that ICT helps increase human capital development and hence has a positive effect on economic growth. Therefore, African economies should implement policies to further develop ICT in order to enjoy the benefits not only from energy efficiency 
improvements but also from human capital development as both lead to economic growth in this continent.

\subsection{Enhancing Economic Growth by Energy-ICT}

Spreng [41] uses a triangle to depict the relationships among energy, information, and growth. The three dimensions are interdependent. ICT can make things smarter, leading to sustainability. That is, ICT can result in the growth type in which less energy and resources are used

Using the data from 1980-2017, Khan et al. [42] find similar empirical evidence from South Asia (consisting of Bhutan, Bangladesh, India, Nepal, Pakistan, and Sri Lanka), showing that an infrastructure including energy-ICT has positive effects on economic growth. They suggest that private investment in energy-ICT and other infrastructure items should be encouraged in order to facilitate economic growth. Analyzing the 1990-2018 data of South Asian economies (including Bangladesh, India, Pakistan, and Sri Lanka), Usman et al. [43] find that in the long run ICT has direct and indirect positive effects that boost economic growth as well as improve energy efficiency. For some economies, ICT has no direct effect on economic growth, but it is found that ICT helps to improve other variables which have positive effects on economic growth. Therefore, ICT has positive direct or indirect effects on economic growth. They also find that ICT helps to reduce $\mathrm{CO}_{2}$ emissions in these South Asian economies. Their empirical findings support the idea that energy-ICT has positive economic as well as environmental effects.

Studying the data of the U.S. from 1981-2017, Adedoyin et al. [44] find that ICT is an important pillar of Industry 4.0. ICT can moderate the impact of foreign direct investment (FDI) on GDP, as well as improve productivity. The energy-led hypothesis is empirically supported in their research. Energy and ICT together enhance the economic growth of the U.S.

Reviewing the development and effects of green ICT in China, Zhang and Liang [45] conclude that ICT contributes a lot to China's energy efficiency improvement, especially in the sectors of manufacturing, building, transportation, agriculture, and public services. The combination of new energy sources and ICT helps replace and reduce the proportion of traditional fossil fuels. ICT can assist the achievement of not only energy goals but also environmental goals. They suggest that green ICT development should be promoted by national-level policies and that pilot demonstration projects are urgently needed to show how green ICT can fit into China's natural and social environment in order to make contributions.

Analyzing the 2002-2012 sectoral data of China, Zhou et al. [46] find that even though ICT accounts for a $4.54 \%$ increase in China's energy intensity, the net effect of ICT development is to reduce energy intensity in China. Moreover, the positive net effects of ICT development are even larger in the service and technology-intensive sectors. They conclude that the deeper and wider development of ICT is preferred from a social viewpoint rather than from the viewpoints of energy savings and productivity enhancement.

Ishida [47] applies the autoregressive distributed lag (ARDL) approach to estimate the effects of ICT development on economic growth and energy consumption in Japan from 1980-2010. It was found that ICT significantly helps the energy demand management, which moderately reduces energy consumption. However, there is no significant statistical evidence to support the idea that ICT has effects on the energy supply side.

Using the South Korean time series data from 1973-2016, Batool et al. [3] find that ICT helps to reduce environmental degradation in the medium and long run. They confirm that ICT can bring benefits in promoting energy-demand management and economic growth as well as carbon reduction. Therefore, the benefits of energy-ICT are multi-faced. They suggest that South Korea should continue to produce more hybrid ICT products (such as those using $5 \mathrm{G}$ technology) and reduce the proportion of non-renewable energy, in order to decrease carbon emissions and environmental degradation at the same time. 
Studying the 1970-2018 data of Tunisia, Lahouel et al. [48] find that energy-ICT helps to improve the total factor productivity and carbon efficiency of this economy. Moreover, the pattern of change is non-linear instead of being linear. Hence, they conclude that energy-ICT has positive effects not only on economic growth but also on climate change mitigation.

\subsection{Energy-ICT Helping Cope with COVID-19}

The whole world has been working on solving issues under the great impact of the COVID-19 pandemic since 2020. The research by Strielkowski et al. [49] points out that ICT is a solution for the world to manage energy systems under the COVID-19 pandemic. The COVID-19 pandemic reduces economic activities, including office work, production, transportation, etc., hence cutting off the energy consumption. ICT then becomes more important for maintaining and monitoring the energy balance than before. They indicate that ICT plays a key role in integrating energy efficiency, energy storage, and renewable energy, which facilitates effective energy management in coping with the COVID-19 pandemic. Consequently, the importance of energy-ICT will be even higher after the COVID-19 pandemic.

With a case study of the Manzanilla area in Spain, García et al. [50] conclude that the smart grid, especially the advance metering infrastructure at secondary distribution networks, helps daily life a lot under lockdowns. They find that residential customers increased their consumption around 15\% under full lockdown and $7.5 \%$ at reopening, whereas nonresidential customers decreased power consumption by $38 \%$ under full lockdown and $14.5 \%$ at reopening. The smart grid helps maintain the power supply and consumption and reduce the impacts. Therefore, the smart grid becomes even more important after the COVID-19 pandemic.

Jiang et al. [51] conclude that the enhancement of ICT, including digitalization and the Internet of Things (IoT), supports the circular economy and renewable energy development under the COVID-19 impact. ICT can foster economic resilience by, for example, handling the emergency needs for transportation and integrating the supply chains, etc. ICT not only helps in coping with the energy challenges but also helps in grasping the energy opportunities.

Comparing the data collected by questionnaires from food industries in Palestine and Malaysia, Mustafa and Abbas [52] find that green ICT helps to sustain the efficiency of the food industry's supply chain and enhances the competitive advantage during the COVID19 pandemic. They also find that green ICT enhances energy efficiency and promotes energy savings. These are because green ICT significantly reduces the wasteful input in stages such as manufacturing, installation, transportation, and so on.

As the above literature review shows, there are already many empirical studies of the cost and benefit of energy-ICT. Even though ICT is an energy-consuming technology, most of the existing empirical studies support the idea that the net effects of energy-ICT are to save energy, improve energy efficiency, and reduce carbon emissions. Energy-ICT becomes a more important technology and operation model after the COVID-19 pandemic outbreak in early 2020.

\section{Fair Competition Issues of Energy-ICT}

When ICT is introduced into a network or platform, it equips the network or platform providers with a high market power of monopolization, to the point that fair competition and antitrust issues may ensue. Similarly, energy-ICT may also increase the market concentration and market power of the platform owner, such that there is a tradeoff between the benefits generated by the positive network effects and the costs brought on by the monopolization of power as energy-ICT is further deployed (see [53-70]).

Compared to selling them separately, recent literature proposes to bundle energy services to better satisfy the consumer demand. That is, an energy service provider should turn into a full-service provider or a total solution provider [53]. The bundling of energy 
services can include bundling different kinds of energy services or bundling energy and non-energy services [54].

In addition to the possible benefits brought by energy-ICT, there may be costs generated by bundling energy and ICT services. Similar to the existing discussion of bundling $([55,56])$, there are tradeoffs between the benefits and costs of bundling energy and ICT services. Even though energy-ICT may improve the production efficiency by generating scale and scope economies and reducing transaction costs, it gives the integrated firm a very high market power across the traditionally separate energy and ICT markets.

Smart grids are by nature a combination of energy and ICT networks, allowing energy firms to have the capabilities of both energy provision and ICT services. Erlinghagen and Markard [57] analyzed 450 European smart grid projects from 2000-2011, showing that incumbent firms in the electricity sector acquired start-ups specialized in ICT technology in order to expand their market power. Energy-ICT thus becomes an effective competition strategy for the energy firms to enrich their own competency. They remind the policy makers and regulators to pay attention to this trend.

Reviewing the smart grid development in Quebec, Canada, Jegen and Philion [58] warn that state-owned electric utility may dominate the policy and then frame smart grid to be a technology advantage, which may bring with it adverse effects on energy market competition. They mention that most of the public attention is on the possible health problems caused by smart meters, but not the effect on sustainability and entrepreneurship. They raise concerns about integrating monopolies with strong connections to the state by the smart grid deployment.

Similar viewpoints that the deployment of smart grids may reinforce the market power of the state-owned incumbent can be found in Mah et al. [59]. They study the case in China and find that even though state-owned companies are the first movers in deploying smart grids, they can also be fundamental blocks against developing higher-order smart grids. As first movers, these state-owned companies enjoy the competitive advantages gained from deploying smart grids first. However, the stronger monopoly power gained by these incumbents may hinder new entrants and future technological progress.

Mamounakis et al. [60] emphasize that the owner of an energy-ICT platform (such as a virtual microgrid aggregator platform of renewable energy sources) has a higher bargaining power and can play as the price maker. Even though the prosumers of renewable energy sources can freely participate in the liberalized market, the owner of such an energy-ICT platform can effectively monitor and manage the prosumers of these renewable energy sources. An appropriate mechanism design for such an energy-ICT platform can help both to create energy savings and to bring money benefits for the end users.

Goldthau [61] warns that the energy-poverty problem may become more serious if there is a lack of governance of the energy infrastructure. Hence, a polycentric framework is needed to blend the scales and engage multiple stakeholder groups in order to avoid the so-called 'tragedy of the commons'. Information at multiple scales should be revealed to these multiple stakeholder groups. Regulatory units should be established at the area level to make decisions.

An energy-ICT platform aims to improve efficiency but has to minimize the risks of the abuse of market power. Clastres [62] suggests that the competitive offerings and the end-user pricing system mechanism on both the supplier and the demand sides should be built. For instance, mechanisms of competitive offerings and end-user pricing systems can eliminate the power of monopolization and hence make both sides competitive. The gains should be allocated fairly among the participants of a platform to make its operation sustainable.

Kranz and Picot [63] emphasize that non-discriminatory access and control rights should be available fairly to the participants in an energy platform. They warn that it is of very high probability that the incumbent operators of the distribution grid will control the smart grid of an integrated energy system. Therefore, the fair competition law and policy should apply to energy-ICT to eliminate bottlenecks generated by the monopolizing power. 
The discriminatory practices by the energy-ICT platform controllers should be annulled and removed.

Bertolini et al. [64] use a theoretical model to show that if the smart grid is built by the incumbent distribution grid operator, then this move will have a preemption effect such that potential competitors cannot easily enter the market. Their theoretical findings match the warnings raised by Kranz and Picot [63]. In order to avoid the monopolization by the incumbent distribution grid operator, Bertolini et al. [64] suggest that a new mechanism including the power generators and end users should be established for an integrated energy-ICT system such as a smart grid.

The fair competition law and policy should also apply to the energy-ICT platforms. Digital platforms are new business models occurring in the era of platform economy. Van Uytsel and Uemura [65] indicate that Japan's Fair Trade Commission has increasing interest in digital platforms to avoid unfair trade measures. In addition to the public and private enforcement against unfair competition behavior, the platforms are welcome to propose commitment plans, including voluntary compliance, to make sure these digital platforms are used fairly by stakeholders and can facilitate transactions in fair ways.

Crispim et al. [66] point out that smart regulations should be imposed on smart grids. They conduct a comparative study of the UK, Italy, and Portugal. Different countries have different regulations, depending on their own characteristics. The UK pays attention to the flexibility of the smart grid. Italy emphasizes the sustainability of the smart grid. Portugal tries to obtain most of the potential benefits of the smart grid. Even though these three countries have different regulations, they all want to reduce greenhouse gas, provide more information, promote green transportation, etc.

Analyzing the development of smart grids in India around 2014, Joseph [67] finds that in each power distribution area there is only one licensee distributor. Therefore, there is no other choice for consumers in this distribution area, making the licensee distributor a monopoly. Therefore, retail competition in a specific area of the smart grid should be enhanced. India has been implementing some pilot projects, such as real-time electricity price sharing, in order to increase the retail market competition.

Mah [68] compared the government-market dynamics in the development of smart grids in China and Japan. Even though both countries aim to develop, diffuse, and utilize smart grid technologies, they adopt different models of government regulations. China's model is more hierarchical, with two monopolized smart grid companies. Japan's model is more systematic, with the implementation of four large-scale demonstration projects. Different countries adopt different competition policies based on their own socio-economic environment.

The OECD [69] proposes that the connection rules to smart grids should be made clear and transparent to all participants. Without a justified reason, the smart grid operator cannot refuse connection from a producer, consumer, or prosumer who meets the smart grid requirements. The costs should be allocated among the participants according to the proportions of their injections. Regulations should be made and enforced to assist the connection of an eligible participant.

Erol-Kantarci et al. [70] propose a 'four-way-handshake protocol' to match loads and storage units and to secure stability of the smart grid and fair access and revenues among the users. That is, they point out that fair access to a smart grid can be provided through a well-designed energy-ICT framework. Because this energy-ICT framework will work according to the rules and algorithms, it can be independent of human intervention and biased self-interest, such that the fair access and sharing can be achieved via an autonomous energy-ICT framework itself.

Summarizing the above literature review, we can find that most of the existing literature on the fair-trade issues of energy-ICT advocates that competition law and policy are required to make the energy-ICT network fairly available to the producers, consumers, and prosumers in the related markets. Energy-ICT can effectively increase the market power of its owners and controllers. Energy-ICT-related law and policy on competition still need 
to be further developed and implemented in order to distribute the cost and benefit of energy-ICT fairly to the market participants.

\section{Cybersecurity Issues of Energy-ICT}

Energy-ICT is an integrated physical-information network. The integration of energy and ICT also inevitably exposes itself to cybersecurity threats (see [6] and [71-86]). Venkatachary et al. [71] remind us that ICT connects multiple sectors as well as that of energy; however, the interdependence of these sectors generates security gaps. The cyber threat causes economic and psychological impacts, as well as huge protection and damage costs. They suggest that global cooperation should be necessary to ensure energy-ICT cybersecurity. For instance, in 2015 a cyberattack on the Ukrainian power grid caused huge area power outages. Because the energy and ICT systems are interconnected, a cyberattack could crash the whole system and bring with it chain reactions. Hence, cybersecurity is a serious issue that any energy-ICT system must face [72].

As Onyeji et al. [73] point out, making the system smarter is making it more vulnerable. The risk of the power system in an economy will increase a lot after the energy-ICT system is installed. It provides additional potential pathways for hackers all over the world. The U.S. has noticed the great threat of cyberattacks on its energy-ICT, such that President Obama signed Executive Order 13636 to improve the critical infrastructure for energy cybersecurity. An economy alone cannot secure energy cybersecurity. Knowledge sharing across borders is needed to enhance the worldwide cyber-security of energy-ICT.

Hawk and Kaushiva [74] indicate that reliability is the fundamental principle for a smart grid. A smarter grid can be riskier. Cybersecurity is imperative and has to be compatible with energy-delivery functions. It is extremely necessary to have the infrastructure ready for rapid restoration from a power outage. The smart grid design must take into account cybersecurity factors, such that during incidents the critical power-delivery functions can be sustained. The objectives of reliability, resilience, and efficiency must be considered simultaneously in designing and building up a smart grid. They give an example of Consolidated Edison of New York, which has expanded its automated overhead switches by $35 \%$ and successfully avoided more than 17,000 user outages. This company also equips itself with the SCADA cybersecurity system to reduce cyberattack risks.

More and more ICT systems have been integrated into the IoT, including energy-ICT. Venkatachary et al. [75] summarize the cybersecurity infrastructure challenges related to power plants under the IoT framework, which include reliability, data security and privacy, big data and networks, law and regulation, institutional barriers, confidentiality, availability, and integrity. They also point out that the cybersecurity of these power plants has two aspects: physical (hardware) and logical (software). They say that the IoT of energy coupled with smart devices is an advanced technology which can be very vulnerable to both physical and logical attacks. The cybersecurity issue becomes extremely important as the deployment of energy-ICT is on track all over the world.

Park and Heo [76] call the days of energy-ICT an 'ICT convergence era'. Via energyICT, the producers and consumers merge into prosumers. New risks emerge as many systems are interlinked by ICT. However, a lot of market participants are not ready with handling the new risks due to ICT convergence. The prosumers' participation, data sharing, and efficient regulations are necessary in the era of ICT convergence.

Papastergiou et al. [77] warn that energy-ICT faces persistent threats and complex incidents. In order to deal with these persistent threats and complex incidents, dynamic, collaborative, warning, and response system components are required. They also demonstrate how solar power production can benefit from an advanced cybersecurity system.

Hecht et al. [78] survey different risk-assessment methods for energy-ICT. Under an energy-ICT network, end users connect to the grid via smart gateways and electricity bills are sent via smart meters. Consequently, every prosumer has her/his own ICT-enabled entry point to the grid, such that cyberattacks can be from anywhere through these multiple entry points. Each existing risk-assessment method for energy-ICT has its advantages and 
limitations, especially as each single method does not cover all the dimensions to check and evaluate. Therefore, there is still a need to further develop the risk-assessment methods for energy-ICT.

Langer et al. [79] suggest that the following three measures should be undertaken for protecting the cybersecurity of a smart grid: effective encryption and authentication mechanisms, minimization of the attack surface, and embedded system security analysis. Most of these cybersecurity measures can apply to an ICT or an IoT system. A smart grid especially needs to protect itself from multi-stage attacks and advanced persistent threats (APTs). There is no free lunch in the world. When people enjoy the benefits of the energy-ICT, the costs of cybersecurity protection must be paid for.

Yang et al. [80] indicate that cybersecurity technologies such as blockchains can help with data security in smart grids. Blockchains can be applied to effectively achieve accountability because malicious behaviors then become traceable. Moreover, these cybersecurity technologies can change the centralized authority into a distributed authority to avoid a single-point failure from becoming a systematic failure. They also demonstrate how to use the edge blockchains technique to design a data-sharing system in a smart grid. Mohammadpourfarda et al. [81] propose an approach to detect physical grid and data manipulation changes in order to prevent attacks with/without concept drift against a smart grid. Advanced technologies are required to ensure cybersecurity.

Pearson [82] shows that Europe has been reinforcing its cybersecurity protection in energy-ICT and incorporating it into its energy policy. Both infrastructure and legislation are required to reduce the vulnerabilities in widely connected smart grids. However, Europe alone cannot do the job well. Europe should cooperate with the U.S. as another early mover in energy-ICT cybersecurity buildup, in order to enjoy complementary benefits.

In addition to the protection from the technology side, the legal protection from the legal side of the cybersecurity of energy-ICT is also required. Mylrea [83] points out that there is still huge room for precedents and laws to evolve in order to reinforce regulations, standards, and legal precedents to protect energy-ICT-related cybersecurity. Europe and the USA have passed new legislations on these issues. The rest of the world can refer to these legal efforts for a sound legal environment to help grow energy-ICT. The nexus of energy ICT and legal studies remains a great research opportunity to explore.

Vernotte et al. [84] present results that show that the cybersecurity system in energyICT can facilitate the load balancing of renewable energy. Even though it is not mainly designed for other purposes, a cybersecurity mechanism can also have the side benefits of stabilizing a power network linked to various energy sources. With a case study in the European High North, Cassotta and Sidortsov [85] show that cybersecurity can link to environmental governance, which can enhance sustainability. The cybersecurity system is an integral part of energy-ICT, which can make other systems operate smoothly. A well-designed and coordinated cybersecurity system can make the whole power system work efficiently [86].

The above literature review indicates that containing cybersecurity issues is crucial to all systems linked by the internet, which of course includes the energy sector. People nowadays live in a global information society and may face the threat of cyberattacks from anywhere at any time. As such, the global development of energy-ICT inevitably incurs the additional costs of maintaining cybersecurity. Cybersecurity technology and energy-ICT technology must co-develop to produce economically sustainable results and a better consumer experience. In addition, the legal institutions should also evolve to provide a sound environment for energy-ICT to grow.

\section{Policies to Promote Energy-ICT}

National policies are important for promoting energy-ICT (see [14] and [87-99]). As the World Energy Council [14] points out, even the developed economies in the EU still need to enhance their legislation to provide sufficient incentives for the development of energy-ICT. Large companies especially should apply low-cost energy ICT. Since the 
2000s, many European member states have been promoting energy-ICT with nationallevel programs, including Austria, Denmark, Finland, France, Germany, Norway, Sweden, the United Kingdom, and so on. The often-seen policy measures include path planning, target announcement, $R \& D$ projects, pilot programs, government spending, public-private partnerships, and so on [87].

Subsidy is one of the most popular industrial policy instruments all over the world. Subsidy can correct market failure caused by the presence of positive externality where social returns are higher than private returns. In addition, subsidy is usually politically feasible in an elective democracy. As Gulati and Pahuja [88] point out, in India subsidy has been used to encourage the nexus of energy-ICT and industries such as agriculture. Subsidy has been an effective policy tool to align the interest of stakeholders and provide financial incentives.

The enterprises can have their own policies and practices to implement energy-ICT. Alinaghian et al. [89] point out that ICT governance should be incorporated with corporate governance. ICT governance is not merely a technology management issue but should be an integral part of corporate governance. ICT has become an enabler for organizations to compete in the market in an information society. The ICT strategies should be aligned with the business objectives. There should be ICT governance guidelines for each organization, incorporated into its corporate governance framework.

Islam [90] finds that the impact of ICT upon business is largely tied to the supporting infrastructure available and the scope of the business in question. Larger and more complex firms have larger positive effects than smaller ones. He also finds that the positive effect is more profound if the ICT integration is adopted on a national scale.

In a study on the effectiveness of ICT on the service industries, Nkosana et al. [91] conclude that cost, lack of owner familiarity with systems, and the corresponding lack of training and familiarity of staff are the main challenges of an ICT transition. These challenges can also apply to the user side of the energy-ICT, especially for small-and medium-sized enterprises (SMEs).

The change in the vehicle power from fossil fuels to electric power can also facilitate energy-ICT development. In addition to government policy, the consumer awareness and behavior change toward relatively environmentally friendly power sources are also key factors [92]. That is, the three kinds of agents in an economy-consumers, firms, and the government should work together to realize a green energy economy backed up by energy-ICT.

A smart city applies ICT to enhance its operational efficiency in order to improve the life quality of the citizens in a sustainable way. The subsystems of energy, water, transportation, health, recycling, etc., are all connected by ICT to deliver sustainable solutions. The negative impacts from the operation of each subsystem can also be reduced. There are already many on-going examples of smart cities in the world, including Dubai, Melbourne, Singapore, etc. The smart city has been a paradigm for a region to be integrated by an energy-ICT system. Studying 15 UK cities with different levels of smartness from 2005-2013, Yigitcanlar and Kamruzzaman [93] found that better alignment among the smart city strategies leads to more sustainable results. The smart city projects which link the subsystems in a region can be effective policy instruments for promoting and realizing energy-ICT, such that the urban development and sustainability can reach a win-win situation.

China exercises its five-year plans to promote the development of smart grids. The fiveyear plans are the grand strategic plans made and announced by the government, indicating the targets to achieve by the whole country. As Deng [94] points out, by upgrading the power system via promoting the ICT-based smart grid, China aims to enhance its industrial foundation and core competitiveness.

Qian et al. [95] also find empirical evidence from China's data that the smart city policy helps promote urban green growth. They analyzed the data of 274 prefecturelevel cities in China from 2004-2017 and found that the smart city policy can significantly 
enhance economic growth, reduce per unit GDP energy consumption, and lower waste emissions. These positive effects are even larger for large cities and non-resource-based cities. Therefore, energy-ICT can be realized and implemented by smart city policies and come up with positive impacts on developing the green energy economy.

Using the methodology of the analytic hierarchy process, Shim et al. [96] found out about the strategic priority of South Korea's green ICT policy. They concluded that cofriendliness, technology, evolution, economic efficiency, energy efficiency, and a stable supply of energy should be the strategic priorities. They recommend international competitiveness as a key tool for promoting green ICT in order to enhance growth in ICT and the energy industry, as well as the macroeconomy.

Yim et al. [97] present a case study of Cheongju City, which is the so-called green capital of South Korea. This city has been transforming itself into a smart green city via urban governance. In addition to the physical infrastructure, such as the smart grid, it is also essential to have the spiritual drivers, such as basic direction, concept, vision, and strategies. Various kinds of stakeholder groups need to work together to realize the smart green city blueprint in this region. An open social governance is necessary to create a cooperative environment to achieve the sustainable development goals.

Green finance is to increase financial flows from various sources of funds to sustainable development items [98]. Green finance has been an effective tool in the market economy for promoting technologies and business models toward sustainability. Analyzing the provincial data in China from 2016-2020, Chang et al. [99] found that green finance has shown its significant effects in mitigating climate change through enhancing energy efficiency and reducing carbon emissions. Green finance is an effective tool for providing economic incentives for enterprises and individuals to adopt new business models such as energy-ICT. In addition to the law and policy amendments, green finance can directly provide efficient and effective incentives to realize and implement energy-ICT.

In summary, the promotion policy toward energy-ICT still needs further elaboration. Moreover, different types of communities and regions, even on as small a scale as the individual cities and towns, may need different promotion-mechanism designs. Among the available policy instruments, government financing of green policies has been a worldwide trend and can be a strong supportive pillar for promoting energy-ICT.

\section{Conclusions}

Energy-ICT as an integrated system can effectively help households, enterprises, and economies achieve SDGs [100] and can eliminate energy and economic inefficiencies. Energy-ICT is re-shaping the business models which create more value for consumers. It has become a worldwide technology-business framework for sustainably working with human societal development. However, energy-ICT may also bring with it adverse effects against SDGs, such as increased energy consumption, the generation of more carbon emissions, cyber-attack vulnerability, the enabling of unfair competition, etc. The positive and negative impacts of energy-ICT must be taken into account at the same time during development. This development should be carefully controlled in both the technological and the institutional aspects in order to obtain the positive net effects that energy-ICT may offer.

This paper reviews the academic journal articles and technical reports of major international organizations with economic and managerial viewpoints related to the energy-ICT and green energy development. It is found that there are four major lines of the existing related literature: cost and benefit analysis, fair competition issues, cybersecurity issues, and promotion policy issues. Even though ICT itself is an energy-consuming technology, most of the empirical studies at the firm or economy-wide levels support the idea that energy-ICT has net positive effects on energy savings, emission reduction, and economic growth. However, there are still non-trivial concerns and challenges with respect to fair competition and the cybersecurity issues of energy-ICT, which have to be solved through mechanism designs combining technology and governance. 
Although government subsidies are often seen and widely adopted all over the world in order to promote energy-ICT, it is also effective to provide the enterprises and consumers with market-mechanism-compatible policies using models such as the smart city. With the implementation of a smart city, enterprises and consumers can voluntarily commit themselves to the development of energy-ICT while enjoying its benefits. As they are not only helpful for large firms, SMEs can also increase their profits through the application of energy-ICT. Though economic as well as environmental benefits can be achieved within a smart city, participants would expectedly act in their own interests. However, under a smart city framework and appropriate government policy different stakeholders would be encouraged to act together to achieve their respective self-interests and SDGs.

Energy-ICT is still in the process of evolving. It includes technological, economic, and management aspects. The whole world is now interconnected through the IoT, and the ongoing inquiry into energy-ICT is part of the IoT's evolution. More opportunities and challenges are ahead as all networks connected by ICT strive to meet SDGs. The future evolution of energy-ICT has to comply with the SDGs in order to help build a smarter green human society. This review article only presents part of the status quo. Future economic and management studies should address the fair competition issues, the business model design, and the governance structure design, etc., of energy-ICT.

Author Contributions: Conceptualization, J.-L.H.; methodology, J.-L.H., Y.-P.Y.; validation, J.-L.H., Y.-C.C. and Y.-P.Y.; formal analysis, J.-L.H.; investigation, J.-L.H.; data curation, J.-L.H., Y.-C.C. and Y.-P.Y.; writing—original draft preparation, J.-L.H.; writing—review and editing, J.-L.H., Y.-C.C. and Y.-P.Y.; visualization, J.-L.H.; supervision, J.-L.H.; project administration, J.-L.H.; funding acquisition, J.-L.H. All authors have read and agreed to the published version of the manuscript.

Funding: Partial financial support from Taiwan's Ministry of Science and Technology (MOST1072410-H-009-035) to the first author is gratefully acknowledged.

Acknowledgments: The authors thank four anonymous referees and an academic editor of this journal for their valuable suggestions.

Conflicts of Interest: The authors declare no conflict of interest.

\section{References}

1. Gibson, L.; Wilman, E.N.; Laurance, W.F. How green is 'green' energy? Trends Ecol. Evol. 2017, 32, 922-935. [CrossRef] [PubMed]

2. Ahmed, F.; Naeem, M.; Iqbal, M. ICT and renewable energy: A way forward to the next generation telecom base stations. Telecommun. Syst. 2016, 64, 43-56. [CrossRef]

3. Batool, R.; Sharif, A.; Islam, T.; Zaman, K.; Shoukry, A.M.; Sharkawy, M.A.; Gani, S.H.; Aamir, A.; Hishan, S.S. Green is clean: The role of ICT in resource management. Environ. Sci. Pollut. Res. 2019, 26, 25341-25358. [CrossRef]

4. Nijhuis, M.; Gibescu, M.; Cobben, J.F.G. Assessment of the impacts of the renewable energy and ICT driven energy transition on distribution networks. Renew. Sust. Energy Rev. 2015, 52, 1003-1014. [CrossRef]

5. Pereira, C.A.; Miorandi, D.; Hatziargyriou, N.; Viejo, P. Complex systems for an ICT-enabled energy system. Procedia Comput. Sci. 2011, 7, 65-67. [CrossRef]

6. Erol-Kantarci, M.; Mouftah, H.T. Energy-Efficient Information and Communication Infrastructures in the Smart Grid: A Survey on Interactions and Open Issues. IEEE Commun. Surv. Tutorials 2014, 17, 179-197. [CrossRef]

7. Farhangi, H. The path of the smart grid. IEEE Power Energy Mag. 2009, 8, 18-28. [CrossRef]

8. Luque, A. The Smart Grid and the Interface between Energy. In ICT and the City Retrofitting and Integrating Urban Infrastructures; Dixon, T., Eames, M., Eds.; Urban Retrofitting for Sustainability; Routledge: New York, NY, USA, 2014; pp. $159-173$.

9. Panajotovic, B.; Jankovic, M.; Odadzic, B. ICT and smart grid. In Proceedings of the 10th International Conference on Telecommunication in Modern Satellite Cable and Broadcasting Services, (TELSIKS), Nis, Serbia, 5-8 October 2011; pp. 118-121. [CrossRef]

10. Wissner, M. The smart grid-A saucerful of secrets? Appl. Energy 2017, 88, 2509-2518. [CrossRef]

11. Ueckerdt, F.; Kempener, R. From Baseload to Peak: Renewables Provide a Reliable Solution 2015, International Renewable Energy Agency (IRENA). Available online: https://www.irena.org/-/media/Files/IRENA/Agency/Publication/2015/IRENA_ Baseload_to_Peak_2015.pdf (accessed on 23 September 2021).

12. Bastida, L.; Cohen, J.J.; Kollmann, A.; Moya, A.; Reichl, J. Exploring the role of ICT on household behavioural energy efficiency to mitigate global warming. Renew. Sustain. Energy Rev. 2019, 103, 455-462. [CrossRef] 
13. Maki, S.; Chandran, R.; Fujii, M.; Fujita, T.; Shiraishi, Y.; Ashina, S.; Yabe, N. Innovative information and communication technology (ICT) system for energy management of public utilities in a post-disaster region: Case study of a wastewater treatment plant in Fukushima. J. Clean. Prod. 2019, 233, 1425-1436. [CrossRef]

14. World Energy Council. The Role of ICT in Energy Efficiency Management: Household Sector 2018. Available online: https: //www.worldenergy.org/assets / downloads/20180420_TF_paper_final.pdf (accessed on 23 September 2021).

15. International Energy Agency. Digitalisation and Energy 2017. Available online: https://www.iea.org/reports/digitalisation-andenergy (accessed on 23 September 2021).

16. Youngman, R. ICT Solutions for Energy Efficiency 2012; World Bank: Washington, DC, USA, 2012; Available online: https: / / openknowledge.worldbank.org/handle/10986/12685 (accessed on 23 September 2021).

17. Thabit, T.H.; Ahmed, H.A.S.; Jasim, Y.A. The impact of green ICT adoption in organizations of developing countries. Al-riyada Bus. Econ. J. 2021, 7, 9-18.

18. International Renewable Energy Agency (IRENA). Energy as a Service: Innovation Landscape Brief 2020. Available online: https: //www.irena.org/-/media/Files/IRENA/Agency/Publication/2020/Jul/IRENA_Energy-as-a-Service_2020.pdf (accessed on 23 September 2021).

19. Plepys, A. The grey side of ICT. Environ. Impact Assess. Rev. 2002, 22, 509-552. [CrossRef]

20. Coroama, V.; Hilty, L.M. Energy Consumed vs. Energy Saved by ICT-A Closer Look; EnviroInfo: Berlin, Germany, 2009.

21. Sugiyama, Y. Green ICT toward Low Carbon Society. In Design or Innovative Value towards a Sustainable Society 2011; Matsumoto, M., Umeda, Y., Masui, K., Fukushige, S., Eds.; Springer: Berlin/Heidelberg, Germany, 2012. [CrossRef]

22. Santarius, T.; Pohl, J.; Lange, S. Digitalization and the decoupling debate: Can ICT help to reduce environmental impacts while the economy keeps growing? Sustainability 2020, 12, 7496. [CrossRef]

23. Klein, T.E.; Richard, P. ICT Energy Challenges, Impact and Solutions. In Proceedings of the 19th International ICIN ConferenceInnovations in Clouds, Internet and Networks, Paris, France, 1-3 March 2016; Available online: http:/ / dl.ifip.org/db/conf/icin/ icin2016/1570254484.pdf (accessed on 23 September 2021).

24. Røpke, I.; Christensen, T.H. Energy impacts of ICT-Insights from an everyday life perspective. Telemat. Inform. 2012, 29 , 348-361. [CrossRef]

25. Malmodin, J.; Lundén, D. The energy and carbon footprint of the global ICT and E\&M sectors 2010-2015. Sustainability 2018, 10, 3027. [CrossRef]

26. Tunali, C.B. The effect of information and communication technology on energy consumption in the European Union countries. $J$. Econ. Sustain. Dev. 2016, 7, 54-60.

27. Cakici, B.; Bylund, M. Changing Behaviour to Save Energy: ICT-Based Surveillance for a Low-Carbon Economy in the Seventh Framework Programme. In Proceedings of the International Conference on ICT for Sustainability, Stockholm, Sweden, 24-27 August 2014; pp. 165-170.

28. Moyer, J.D.; Hughes, B.B. ICTs: Do they contribute to increased carbon emissions? Technol. Forecast. Soc. Chang. 2012, 79, 919-931. [CrossRef]

29. Niyibizi, A.; Komakech, A. Climate Change Mitigation in Developing Countries Using ICT as an Enabling Tool. In ClimateSmart Technologies. Climate Change Management; Leal Filho, W., Mannke, F., Mohee, R., Schulte, V., Surroop, D., Eds.; Springer: Berlin/Heidelberg, Germany, 2013. [CrossRef]

30. Ngwenyama, O.; Morawczynski, O. Factors affecting ICT expansion in emerging economies: An analysis of ICT infrastructure expansion in five Latin American countries. Inf. Technol. Dev. 2009, 15, 237-258. [CrossRef]

31. Ponce-Jara, M.; Ruiz, E.; Gil, R.; Sancristóbal, E.; Pérez-Molina, C.; Castro, M. Smart grid: Assessment of the past and present in developed and developing countries. Energy Strat. Rev. 2017, 18, 38-52. [CrossRef]

32. Colak, I.; Bayindir, R.; Fulli, G.; Tekin, I.; Demirtas, K.; Covrig, C.F. Smart grid opportunities and applications in Turkey. Renew. Sustain. Energy Rev. 2014, 33, 344-352. [CrossRef]

33. Mattern, F.; Staake, T.; Weiss, M. ICT for Green How Computers Can Help Us to Conserve Energy. In Proceedings of the 1st International Conference on Energy-Efficient Computing and Networking, Passau, Germany, 13-15 April 2010; pp. 1-10. [CrossRef]

34. Lange, S.; Pohl, J.; Santarius, T. Digitalization and energy consumption. Does ICT reduce energy demand? Ecol. Econ. 2020, 176, 106760. [CrossRef]

35. Molderink, A.; Bosman, M.G.C.; Bakker, V.; Hurink, J.L.; Smit, G.J.M. Simulating the Effect on the Energy Efficiency of Smart Grid Technologies. In Proceedings of the 2009 Winter Simulation Conference (WSC), Austin, TX, USA, 13-16 December 2009; pp. 1530-1541. [CrossRef]

36. Anjana, K.; Shaji, R. A review on the features and technologies for energy efficiency of smart grid. Int. J. Energy Res. 2017, 42, 936-952. [CrossRef]

37. Yan, Z.; Shi, R.; Yang, Z. ICT Development and sustainable energy consumption: A perspective of energy productivity. Sustainability 2018, 10, 2568. [CrossRef]

38. Schulte, P.; Welsch, H.; Rexhäuser, S. ICT and the demand for energy: Evidence from OECD countries. Environ. Resour. Econ. 2014, 63, 119-146. [CrossRef] 
39. Lu, W.C. The impacts of information and communication technology, energy consumption, financial development, and economic growth on carbon dioxide emissions in 12 Asian countries. Mitig. Adapt. Strat. Glob. Chang. 2018, 23, 1351-1365. [CrossRef]

40. Chimbo, B. Energy consumption, information and communication technology and economic growth in an African context. Int. J. Energy Econ. Policy 2020, 10, 486-493. [CrossRef]

41. Spreng, D. The Interdependency of Energy, Information, and Growth. In ICT Innovations for Sustainability. Advances in Intelligent Systems and Computing; Hilty, L., Aebischer, B., Eds.; Springer: Cham, Switzerland, 2015; pp. 425-4310. [CrossRef]

42. Khan, H.; Khan, U.; Jiang, L.J.; Khan, M.A. Impact of infrastructure on economic growth in South Asia: Evidence from pooled mean group estimation. Electr. J. 2020, 33, 106735. [CrossRef]

43. Usman, A.; Ozturk, I.; Hassan, A.; Zafar, S.M.; Ullah, S. The effect of ICT on energy consumption and economic growth in South Asian economies: An empirical analysis. Telemat. Inform. 2020, 58, 101537. [CrossRef]

44. Adedoyin, F.F.; Bekun, F.V.; Driha, O.M.; Balsalobre-Lorente, D. The effects of air transportation, energy, ICT and FDI on economic growth in the industry 4.0 era: Evidence from the United States. Technol. Forecast. Soc. Chang. 2020, 160, 120297. [CrossRef]

45. Zhang, J.; Liang, X.-J. Promoting green ICT in China: A framework based on innovation system approaches. Telecommun. Policy 2012, 36, 997-1013. [CrossRef]

46. Zhou, X.; Zhou, D.; Wang, Q. How does information and communication technology affect China's energy intensity? A three-tier structural decomposition analysis. Energy 2018, 151, 748-759. [CrossRef]

47. Ishida, H. The effect of ICT development on economic growth and energy consumption in Japan. Telemat. Inform. 2015, 32, 79-88. [CrossRef]

48. Lahouel, B.B.; Taleb, L.; Zaied, Y.B.; Managi, S. Does ICT change the relationship between total factor productivity and $\mathrm{CO}_{2}$ emissions? Evidence based on a nonlinear model. Energy Econ. 2021, 101, 105406. [CrossRef]

49. Strielkowski, W.; Firsova, I.; Lukashenko, I.; Raudeliūnienè, J.; Tvaronavičienè, M. Effective management of energy consumption during the COVID-19 pandemic: The role of ICT solutions. Energies 2021, 14, 893. [CrossRef]

50. García, S.; Parejo, A.; Personal, E.; Guerrero, J.I.; Biscarri, F.; León, C.A. retrospective analysis of the impact of the COVID-19 restrictions on energy consumption at a disaggregated level. Appl. Energy 2021, 287, 116547. [CrossRef] [PubMed]

51. Jiang, P.; Van Fan, Y.; Klemeš, J.J. Impacts of COVID-19 on energy demand and consumption: Challenges, lessons and emerging opportunities. Appl. Energy 2021, 285, 116441. [CrossRef]

52. Mustafa, M.; Abbas, A. Comparative analysis of green ICT practices among Palestinian and Malaysian in SME food enterprises during Covid-19 Pandemic. PalArch's J. Archaeol. Egypt Egyptol. 2021, 18, 254-264.

53. Fell, M. Energy services: A conceptual review. Energy Res. Soc. Sci. 2017, 27, 129-140. [CrossRef]

54. Eakin, K.; Faruqui, A. Bundling value-added and commodity services in retail electricity markets. Electr. J. 2000, 13, 60-68. [CrossRef]

55. Chung, H.L.; Lin, Y.S.; Hu, J.L. Bundling strategy and product differentiation. J. Econ. 2012, 108, 207-229. [CrossRef]

56. Chung, H.L.; Chen, H.Y.; Hu, J.L.; Lin, Y.S. Bundling with quality choice. Hitotsubashi J. Econ. 2014, 55, $147-165$.

57. Erlinghagen, S.; Markard, J. Smart grids and the transformation of the electricity sector: ICT firms as potential catalysts for sectoral change. Energy Policy 2012, 51, 895-906. [CrossRef]

58. Jegen, M.; Philion, X.D. Smart grid development in Quebec: A review and policy approach. Renew. Sustain. Energy Rev. 2018, 82, 1922-1930. [CrossRef]

59. Mah, D.N.-Y.; Wu, Y.-Y.; Hills, P.R. Explaining the role of incumbent utilities in sustainable energy transitions: A case study of the smart grid development in China. Energy Policy 2017, 109, 794-806. [CrossRef]

60. Mamounakis, I.; Vergados, D.J.; Makris, P.; Varvarigos, E. A Virtual Microgrid Aggregator Platform for Distributed and SmallScale RES Prosumers Management. In Proceedings of the IEICE Information and Communication Technology Forum, Patras, Greece, 6-7 July 2016.

61. Goldthau, A. Rethinking the governance of energy infrastructure: Scale, decentralization and polycentrism. Energy Res. Soc. Sci. 2014, 1, 134-140. [CrossRef]

62. Clastres, C. Smart grids: Another step towards competition, energy security and climate change objectives. Energy Policy 2011, 39, 5399-5408. [CrossRef]

63. Kranz, J.J.; Picot, A. Toward an End-to-End Smart Grid: Overcoming Bottlenecks to Facilitate Competition and Innovation in Smart Grids; National Regulatory Research Institute: Alexandria, MY, USA, 2011.

64. Bertolini, M.; Buso, M.; Greco, L. Competition and Regulation with Smart Grids; Marco Fanno Working Papers No. 226. Padova, Italy, 2018. Available online: https://economia.unipd.it/sites/decon.unipd.it/files/20180226.pdf (accessed on 17 December 2021).

65. Van Uytsel, S.; Uemura, Y. Regulating Competition between Digital Platforms: The Japan Fair Trade Commission's Preference for Unfair Trade Practices. In The Digital Economy and Competition Law in Asia. Perspectives in Law, Business and Innovation; Van Uytsel, S., Ed.; Springer: Singapore, 2021; pp. 45-72. [CrossRef]

66. Crispim, J.; Braz, J.; Castro, R.; Esteves, J. Smart grids in the EU with smart regulation: Experiences from the UK, Italy and Portugal. Util. Policy 2014, 31, 85-93. [CrossRef]

67. Joseph, A. Smart grid and retail competition in India: A review on technological and managerial initiatives and challenges. Procedia Technol. 2015, 21, 155-162. [CrossRef] 
68. Mah, D.N.-Y. Conceptualising government-market dynamics in socio-technical energy transitions: A comparative case study of smart grid developments in China and Japan. Geoforum 2020, 108, 148-168. [CrossRef]

69. OECD. Electricity: Renewables and Smart Grids 2010. Available online: https://www.oecd.org/competition/sectors/46586020 .pdf (accessed on 6 January 2022).

70. Erol-Kantarci, M.; Sarker, J.H.; Mouftah, H.T. A four-way-handshake protocol for energy forwarding networks in the smart grid. Ad Hoc Netw. 2014, 22, 83-92. [CrossRef]

71. Venkatachary, S.K.; Prasad, J.; Samikannu, R. Cybersecurity and cyber terrorism-in energy sector-a review. J. Cyber Secur. Technol. 2018, 2, 111-130. [CrossRef]

72. Sun, C.C.; Hahn, A.; Liu, C.C. Cyber security of a power grid: State-of-the-art. Int. J. Electr. Power Energy Syst. 2018, 99, 45-56. [CrossRef]

73. Onyeji, I.; Bazilian, M.; Bronk, C. Cyber security and critical energy infrastructure. Electr. J. 2014, 27, 52-60. [CrossRef]

74. Hawk, C.; Kaushiva, A. Cybersecurity and the smarter grid. Electr. J. 2014, 27, 84-95. [CrossRef]

75. Venkatachary, S.K.; Prasad, J.; Samikannu, R.; Alagappan, A.; Andrews, L.J.B. Cybersecurity infrastructure challenges in IoT based virtual power plants. J. Stat. Manag. Syst. 2020, 23, 263-276. [CrossRef]

76. Park, C.; Heo, W. Review of the changing electricity industry value chain in the ICT convergence era. J. Clean. Prod. 2020, 258, 120743. [CrossRef]

77. Papastergiou, S.; Mouratidis, H.; Kalogeraki, E.-M. Handling of advanced persistent threats and complex incidents in healthcare, transportation and energy ICT infrastructures. Evol. Syst. 2020, 12, 91-108. [CrossRef]

78. Hecht, T.; Langer, L.; Smith, P. Cybersecurity Risk Assessment in Smart Grids. ComForEn. 2014, pp. 1-8. Available online: https:/ / project-sparks.eu/wp-content/uploads/2014/04/SmartGridRiskAssessment_ComForEn14_camera-ready.pdf (accessed on 17 December 2021).

79. Langer, L.; Skopik, F.; Smith, P.; Kammerstetter, M. From old to new: Assessing cybersecurity risks for an evolving smart grid. Comput. Secur. 2016, 62, 165-176. [CrossRef]

80. Yang, W.; Guan, Z.; Wu, L.; Du, X.; Guizani, M. Secure data access control with fair accountability in smart grid data sharing: An edge blockchain approach. IEEE Internet Things J. 2021, 8, 8632-8643. [CrossRef]

81. Mohammadpourfard, M.; Weng, Y.; Pechenizkiy, M.; Tajdinian, M.; Mohammadi-Ivatlooe, B. Ensuring cybersecurity of smart grid against data integrity attacks under concept drift. Int. J. Electr. Power Energy Syst. 2020, 119, 105947. [CrossRef]

82. Pearson, I.L. Smart grid cyber security for Europe. Energy Policy 2011, 39, 5211-5218. [CrossRef]

83. Mylrea, M. Smart energy-internet-of-things opportunities require smart treatment of legal, privacy and cybersecurity challenges. J. World Energy Law Bus. 2017, 10, 147-158. [CrossRef]

84. Vernotte, A.; Välja, M.; Korman, M.; Björkman, G.; Ekstedt, M.; Lagerström, R. Load balancing of renewable energy: A cyber security analysis. Energy Informatics 2018, 1, 5. [CrossRef]

85. Cassotta, S.; Sidortsov, R. Sustainable cybersecurity? Rethinking approaches to protecting energy infrastructure in the European High North. Energy Res. Soc. Sci. 2019, 51, 129-133. [CrossRef]

86. Alibasic, A.; Al Junaibi, R.; Aung, Z.; Woon, W.L.; Omar, M.A. Cybersecurity for Smart Cities: A Brief Review. In Data Analytics for Renewable Energy Integration. DARE 2016. Lecture Notes in Computer Science 7; Woon, W., Aung, Z., Kramer, O., Madnick, S., Eds.; Springer: Cham, Switzerland, 2017; Volume 122, p. 30097. [CrossRef]

87. Hilty, L.M.; Coroama, V.; de Eicker, M.O.; Ruddy, T.F.; Müller, E. The Role of ICT in Energy Consumption and Energy Efficiency; Empa Swiss Federal Laboratories for Materials Testing and Research: St. Gallen, Switzerland, 2009.

88. Gulati, M.; Pahuja, S. Direct delivery of power subsidy to manage energy-ground water-agriculture nexus. Aquat. Procedia 2015, 5, 22-30. [CrossRef]

89. Alinaghian, R.; Rahman, A.A.; Ibrahim, R. Information and communication technology (ICT) policy: Significances, challenges, issues and future research framework. Aust. J. Basic Appl. Sci. 2011, 5, 963-969.

90. Islam, $\mathrm{N}$. The use of information and communication technology (ICT) and business management: Contemporary issues and challenges. SSRN Electron. J. 2016. [CrossRef]

91. African Journal of Hospitality, Tourism and Leisure. 2022. Available online: https://www.ajhtl.com/ (accessed on 23 September 2021).

92. Ho, C.W.; Wu, C.C. Exploring Intention toward using an electric scooter: Integrating the technology readiness and acceptance into norm activation model (TRA-NAM). Energies 2021, 14, 6895. [CrossRef]

93. Yigitcanlar, T.; Kamruzzaman, M. Does smart city policy lead to sustainability of cities? Land Use Policy 2018, 73, 49-58. [CrossRef]

94. Deng, H. The development of smart grid and the legal challenges in China. Jindal Glob. Law Rev. 2015, 6, 123-136. [CrossRef]

95. Qian, Y.; Liu, J.; Cheng, Z.; Forrest, J.Y.L. Does the smart city policy promote the green growth of the urban economy? Evidence from China. Environ. Sci. Pollut. Res. 2021, 28, 66709-66723. [CrossRef]

96. Shim, Y.H.; Kim, K.Y.; Cho, J.Y.; Park, J.K.; Lee, B.G. Strategic priority of green ICT policy in Korea: Applying analytic hierarchy process. Int. J. Environ. Eng. 2009, 3, 301-305.

97. Yim, K.H.; Ha, M.C.; Jo, C.J.; Han, K.-M.; Baek, J.I.; Ban, Y.U. Strategic planning for the smart-green city through urban governance. Int. J. Built Environ. Sustain. 2015, 2. [CrossRef]

98. UN Environment Programme. Green Financing. Available online: https://www.unep.org/regions/asia-and-pacific/regionalinitiatives / supporting-resource-efficiency/green-financing (accessed on 21 October 2021). 
99. Chang, L.; Wang, J.; Xiang, Z.; Liu, H. Impact of Green financing on carbon drifts to mitigate climate change: Mediating role of energy efficiency. Front. Energy Res. 2021, 9. [CrossRef]

100. Modi, V.; Figueroa, H.P. Sustainable Development Goal for Energy and Information and Communications Technologies. UN Chronicle 2015. Available online: https:/ / www.un.org/en/chronicle/article/sustainable-development-goal-energy-andinformation-and-communications-technologies (accessed on 23 September 2021). 